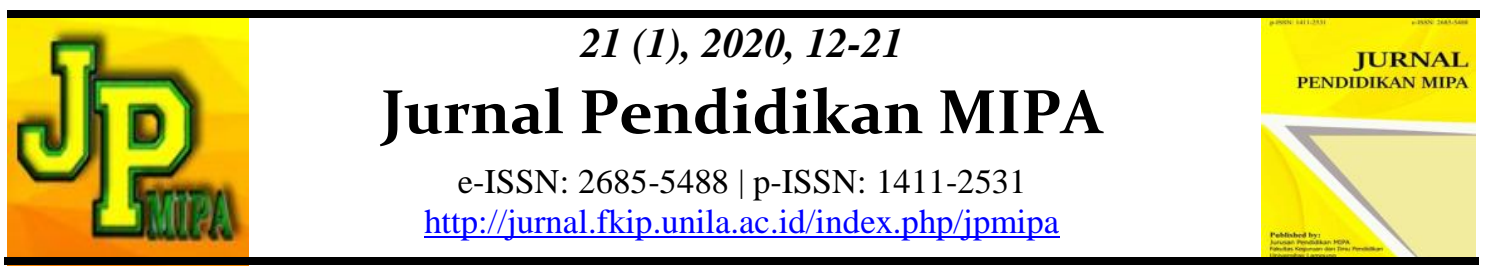

\title{
Metacognitive Analogy Instruction: Effects on Students' Reflective Thinking in Learning Biology
}

\author{
Reynald Alfred Auzana Recede ${ }^{1}$, Ariel Tacluyan Capati ${ }^{2}$, Rosanelia Tablico Yangco ${ }^{3}$, \\ Mark Agustin Castro \\ ${ }^{1}$ Marikina High School, Philippines \\ ${ }^{2}$ Department of Biology Education, Institute of Education, Far Eastern University, Philippines \\ ${ }^{3}$ College of Education, University of the Philippines, Philippines \\ ${ }^{4}$ Fortune High School, Philippines
}

\begin{abstract}
This study examined the effects of Metacognitive Analogy Instruction (MAI) on the students' reflective thinking skills in Biology at the secondary level. A two-group pretestposttest quasi experimental design was used to teach the control group using NonMetacognitive Analogy Instruction (NMAI) which includes traditional way of teaching like lecture discussions, while the experimental group was taught using the Metacognitive Analogy Instruction. Results showed that students exposed to MAI improved better $(M=11.30)$ than those exposed to NMAI on the Habitual Action dimension $(\mathrm{M}=10.09)$ of reflective thinking ( $\mathrm{p}=$ $0.001)$ but the two groups had comparable performance $(\mathrm{p}=0.42 ; 0.18 ; 0.09 ; \& 0.10)$ on the Understanding ( $\mathrm{M}=14.40)$, Reflection $(\mathrm{M}=12.47)$, and Critical Reflection dimensions $(\mathrm{M}=$ 12.73). The improvement of the MAI group in their overall reflective thinking skills scores particularly in the Habitual Action dimension could be attributed to the use of metacognitive analogies as part of the class instruction which required a considerable amount of focus and thinking. Hence, it is recommended that MAI be used for classroom instruction, curricular and instructional development, and teacher trainings to improve reflective thinking skills among students.
\end{abstract}

Keywords: metacognition, metacognitive analogy, reflective thinking.

Abstrak: Penelitian ini menguji dampak dari Metacognitive Analogy Instruction (MAI) pada keterampilan berpikir reflektif siswa dalam pembelajaran Biologi SMA. Desain kuasi eksperimen dengan pretest-posttest dua kelompok digunakan untuk mengajar kelompok kontrol menggunakan Non-Metacognitive Analogy Instruction (NMAI) yang mencakup cara pengajaran tradisional seperti diskusi, sedangkan kelompok eksperimen diajarkan menggunakan Metacognitive Analogy Instruction. Hasil penelitian menunjukkan bahwa dimensi Habitual Action meningkat lebih baik pada siswa yang diterapkan MAI $(M=11,30)$ dari berpikir reflektif $(p=0,001)$ daripada NMAI $(M=10,09)$ tetapi kedua kelompok memiliki performa yang sebanding $(p=0,42 ; 0,18 ; 0,09 ; \& 0,10)$ pada dimensi Understanding $(M=14,40)$, Refleksi $(M=12,47)$, dan Critical Reflection $(M=12,73)$. Peningkatan skor keterampilan berpikir reflektif keseluruhan pada kelompok MAI terutama dalam dimensi Habitual Action dapat dikaitkan dengan penggunaan analogi metakognitif sebagai bagian dari pembelajaran dalam kelas yang lebih membutuhkan fokus dan pemikiran. Oleh karena itu, MAI direkomendasikan untuk digunakan pada pembelajaran di kelas, pengembangan kurikulum dan pengajaran, dan pelatihan guru untuk meningkatkan keterampilan berpikir reflektif siswa.

Keywords: metakognisi, analogi metakognitif, berpikir reflektif.

Ariel Tacluyan Capati

Email: acapati@feu.edu.ph
DOI: http://dx.doi.org/10.23960/jpmipa/v21i1.pp12-21

Received: 21 February 2020

Accepted: 13 March 2020 


\section{- INTRODUCTION}

Many Filipino learners in the public school system fail to see the importance of education due to a lot of reasons. Some of these reasons are lack of interest in schooling, insufficient financial resources, and absence of parental support (Amoroso \& Bajo, 2014). Among the three aforementioned reasons, the lack of interest in schooling usually keeps students away from the academic environment. They tend to believe that education has little to do with their everyday lives. It is also noted that Filipino students ranked very low in international tests in science as compared to other participating countries. According to the results of the 2003 Trends in International Mathematics and Science Study (TIMSS) conducted by the International Association for the Evaluation of Educational Achievement (IEA), the Philippines ranked 23rd out of 25 countries in Grade 4, and 42nd among 45 countries in Grade 8 (second year high school) for science (Mullis et al., 2004). For mathematics, the country ranked 23rd in Grade 4 and 41st in Grade 8 (second year high school) along with countries like Chile, Morocco, Tunisia, and South Africa in the bottom group (Mullis et al. as cited in Feliciano et al., 2005). This poor student achievement result has prompted educational researchers worldwide to continuously identify factors that can account for academic outcomes in the classroom (Orleans, 2007). On the same note, the 2018 Programme for International Student Assessment (PISA) revealed that Philippines, out of 88 countries all over the world, ranked second from the bottom, with a 357 science average score (OECD, PISA 2018 Database). PISA results show learning outcomes, in the context of quality and equity, attained around the world. These outcomes are indicators of competencies needed for the 21 st century societal demands. As we move towards the uncertain future, educators and policy makers are in the better position to craft policies and change practices via the aforesaid results.

In the area of science education, it is considered an important task of teachers to make science concepts more relevant to students, more easily learned, and more reflective of the actual practice of science. Moreover, educational institutions in the Philippines are directed to focus on nurturing well- rounded individuals, not only in their intellectual and academic aspects, but on other important qualities such as character and values, which can be developed through guided reflection. It is then considered that metacognition is a valuable process in education, and is often described as "thinking about thinking". It is a deliberate, planful, intentional, goal- directed, future- oriented mental behavior that is useful to accomplish cognitive tasks (Flavell, 1979). Metacognition is the ability to use existing knowledge in coming up with a strategy for approaching learning tasks, take necessary steps to problem solve, reflect on and evaluate results, and modify one's approach as needed. It is also considered that reflective thinking, which is an important variable in this study, allows individuals to feel responsible for their own learning, to determine their own objectives, and to take part in learning processes (Demir, 2015). Students must develop reflective thinking skills in order to come up with sound judgment and decisions that can be applied in reallife situations. Reflective thinking aids in metacognition in the way that students are able to reflect and analyze the things that they have learned.

In the search for ways to develop motivated and reflective thinking students, it is found that analogies could help in this aspect. Analogies then have been widely used in many classroom situations. Analogy is a process of identifying similarities between two concepts. The familiar concept is called the analog and the unfamiliar science concept is called the target (Ugur et al., 2012). For a student to come up with an appropriate 
analogy, he/she has to think and reflect for the most suitable word which is comparable to what they are trying to study. Analogies motivate students to learn by provoking their interest (Sendur et al., 2011). In addition to this, teachers emphasize the importance of using analogy for the development of students' reasoning ability. Learners show satisfaction with their ability to perceive the analogy and to easily understand the associated new construct (Jonāne, 2015). Students' ability to recognize how they learn while creating the analogy is clear evidence that they are going through metacognition.

Most foreign studies (Akkuzu \& Akcay, 2011; Harrison \& Treagust, 1993; Ugur, Dilber, Senpolat, \& Duzgun, 2012) have found out that the use of analogy in instruction helped developed conceptual understanding among students. It was also revealed that the use of analogy is more effective if the object where the new concept is compared to is something that the learner is already familiar with. This is also one reason why students must be taught to reflect and evaluate on whatever material is used. Existing studies on analogy showed how it enhanced student learning significantly. However, studies undertaken did not specifically explore the effects of metacognitive analogy on the students' reflective thinking and motivation in Biology. Hence, it is here where this study is considered important.

The study investigated the effects of Metacognitive Analogy Instruction on Grade 10 junior high school students' reflective thinking in Biology. Specifically, it sought answers to the following question: Do students exposed to Metacognitive Analogy Instruction (MAI) have higher mean posttest score in the Reflective Thinking Questionnaire (RTQ) in Biology than those exposed to Non-Metacognitive Analogy Instruction (NMAI) in terms of habitual action, understanding, reflection, and critical reflection?

\section{Conceptual Framework}

Students are having difficulty in comprehending many science concepts which are too technical for them or are out of their life context. The construct of science education has been encouraging science teachers to use varying strategies that are engaging and meaningful to students. One of the strategies available is the use of analogy which had already shown its impact in the achievement of students (Baker \& Lawson, as cited in Remigio, 2012). Learners are supposed to be involved with the learning process and this can be achieved when teachers provide activities which allow students to think and assess their own learning. They should be able to know how to evaluate and gauge where they truly are. Teachers should be able to help students reflect on whatever content presented to them. Student motivation is an important gauge of academic performance and achievement (Maurer, 2013). Students get excited when they have the feeling that they are getting what they are supposed to learn from a lesson.

Although some studies on the use of analogy have been conducted in the Philippines, its effect on reflective thinking skills has not been explored. Thus, instead of just using simple analogy, the goal is to see if the use of metacognitive analogies results to better learning thru reflective thinking skills. The conceptual framework below features two teaching approach, the Metacognitive Analogy Instruction (MAI) and the Non-Metacognitive Analogy Instruction (NMAI). The effects of these approaches on the reflective thinking skills toward learning Biology among Grade 10 junior high school students were the focus of this study. 


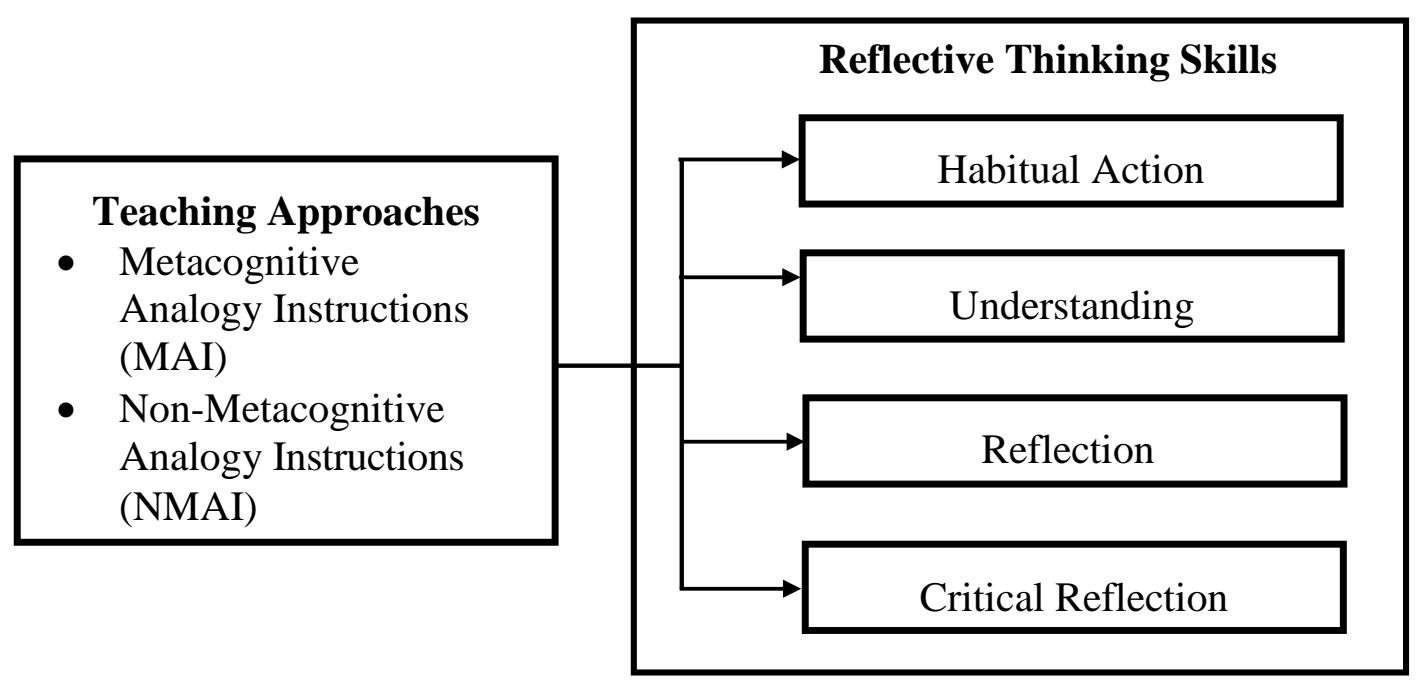

Figure 1. Conceptual framework

The conceptual framework shows the relationship of the two approaches of instruction to reflective thinking skills students in learning Biology. The independent variable is the teaching approach categorized as MAI and NMAI while the dependent variable is the reflective thinking skill is typologized as the habitual action, understanding, reflection, and critical reflection (Kember, et.al., 2000).

\section{- METHOD}

The study utilized a quasi-experimental pretest-posttest design with two intact classes to test the effectiveness of Metacognitive Analogy Instruction (MAI) on students' reflective thinking skills in Biology. One group was exposed to Metacognitive Analogy Instruction (MAI) and the other group was exposed to Non-Metacognitive Analogy Instruction (NMAI). Students exposed to Metacognitive Analogy Instruction were taught lessons in Grade 10 Biology while using metacognitive analogies. The students themselves were the ones who thought of the analogies that can be compared with the concepts that were part of the lesson. They ask themselves metacognitive questions for them to be sure they have the right analogy in mind. This step is of big help to avoid confusion on the part of the learners. On the other hand, students exposed to Non-Metacognitive Analogy Instruction were taught Grade 10 Biology lessons using traditional teaching strategies like lectures, discussions, cooperative learning and other conventional teaching strategies. Both groups were exposed to MAI and NMAI for 8 weeks. The participants were 89 out of 100 junior high school students from two classes of a public national high school in San Mateo, Rizal, Philippines during the School Year 2016-2017. The sample was reduced to 89 because of the absences incurred by some students.

The instrument, Reflective Thinking Questionnaire, was devised by Kember et.al. (2000) to assess reflective thinking skills of the students. It categorized reflective thinking in four dimensions (subscales) such as Habitual Action, Understanding, Reflection, and Critical Reflection. The items in the questionnaire were translated into the Filipino language. The instrument was pilot-tested among Grade 11 senior high school students on August 25, 2016. It was found to have a Cronbach's alpha of .73 that indicates relatively good internal consistency. 
Pretest and posttest mean scores from the Reflective Thinking Questionnaire were the main data gathered for the study. The instrument was administered before and after instruction to both groups. Independent samples t-test was conducted for the pretest mean scores of the two groups for initial comparability and the posttest mean scores to determine if the experimental group performed better than the control group. Paired samples t-test was utilized to determine if there was an improvement after the intervention. Significance level was set at $\alpha=.05$.

The two groups were taught using two different instructions - Metacognitive Analogy Instruction and Non-Metacognitive Analogy Instruction. The experimental group was taught using Metacognitive Analogy Instruction. This approach used science activities in Grade 10 Biology which employed metacognitive analogies where students carefully planned and selected the analogy that they would use for a certain target concept. Next, they reflected and analyzed why the chosen familiar concept was the best option to explain the target concept. Lastly, they presented their analogies to their classmates for final evaluation. On the other hand, the control group received NonMetacognitive Analogy Instruction. It is different from the experimental group because metacognitive analogies were not integrated into the teaching of biology concepts. It only involved the use of traditional teaching strategies like lecture methods, discussion, and cooperative learning to name a few. The topics, delivery strategies and learning or scaffolding activities for the NMAI group were the same as those for the MAI group except the use of metacognitive analogies. The topics covered were Grade 10 biology lessons included in the Philippine Department of Education curriculum guide. The intervention lasted for six months.

\section{- RESULT AND DISCUSSION}

\section{Initial Comparability of MAI and NMAI Groups}

Table 1 below highlights the pretest mean scores in the Reflective Thinking Questionnaire (RTQ). This was done to establish comparability of students from the two groups, Metacognitive Analogy Instruction (MAI) group and Non-Metacognitive Analogy Instruction (NMAI) group, before study implementation.

Table 1. MAI and NMAI pretest mean scores in the Reflective Thinking Questionnaire

\begin{tabular}{lllllll}
\hline Data & Group & Mean & $\begin{array}{l}\text { Std. } \\
\text { Dev. }\end{array}$ & t & df & $\begin{array}{l}\text { Sig (2- } \\
\text { tailed) }\end{array}$ \\
\hline Habitual Action & MAI & 10.64 & 1.93 & -0.86 & 87 & 0.39 \\
& NMAI & 10.33 & 1.35 & & & \\
Understanding & MAI & 14.52 & 1.28 & 1.96 & 87 & 0.05 \\
& NMAI & 13.93 & 1.54 & & & \\
Reflection & MAI & 13.18 & 1.48 & 1.39 & 87 & 0.17 \\
& NMAI & 12.78 & 1.26 & & & \\
Critical Reflection & MAI & 12.02 & 1.65 & 0.001 & 87 & 0.1 \\
& NMAI & 12.73 & 1.80 & & & \\
Reflective Thinking & MAI & 50.36 & 3.60 & 1.74 & 87 & 0.86 \\
Skills (Overall) & NMAI & 49.07 & 3.44 & & & \\
\hline
\end{tabular}

Result showed an overall $\mathrm{p}$ value of .86 which is greater than .05 , indicating that there is no significant difference in the pretest mean scores of the MAI group ( $M=50.36$, $\mathrm{SD}=3.60)$ and the NMAI group $(\mathrm{M}=49.07, \mathrm{SD}=3.44)$ in their RTQ result. This result 
suggests that the students' reflective thinking skills were comparable before the intervention. In addition to this, the same table shows that the pretest mean scores of the MAI students in the Habitual Action $(\mathrm{M}=10.64, \mathrm{SD}=1.93)$, Understanding $(\mathrm{M}=14.52$, $\mathrm{SD}=1.28)$ and Reflection $(\mathrm{M}=13.18, \mathrm{SD}=1.48)$ dimensions are numerically higher compared to those of the NMAI students $(\mathrm{M}=10.33, \mathrm{SD}=1.35 ; \mathrm{M}=13.93, \mathrm{SD}=1.54$; $\mathrm{M}=12.78, \mathrm{SD}=1.26$ ). However, it is important to note that in the Understanding dimension, the difference between the pretest mean scores of the two groups is significant ( $\mathrm{p}=.05)$ in favor of the MAI group.

Analysis of Covariance (ANCOVA) was employed to determine if the significant difference of the pretest mean scores in the Understanding dimension of reflective thinking affected the posttest mean scores of the students after the intervention. It is recommended that future researchers match the students' scores generated by the instruments so that the MAI and NMAI groups are comparable before the intervention.

Table 2. ANCOVA with posttest on understanding dimension of reflective thinking

\begin{tabular}{llllll}
\hline Source & $\begin{array}{l}\text { Type III Sum of } \\
\text { Squares }\end{array}$ & df & Mean Square & F & Sig. \\
\hline Corrected Model & $7.728^{\mathrm{a}}$ & 1 & 7.728 & 3.825 & 0.054 \\
Intercept & 18014.605 & 1 & 18014.61 & 8916. & 0 \\
& & & & 2 & \\
Group & 7.728 & 1 & 7.728 & 3.825 & 0.054 \\
Error & 175.777 & 87 & 2.02 & & \\
Total & 18192 & 89 & & & \\
Corrected Total & 183.506 & 88 & & & \\
\hline a. $\mathrm{r}^{2}=.042$ (Adjusted $\left.\mathrm{r}^{2}=.031\right)$ & & &
\end{tabular}

Table 2 highlighted that the pretest scores in the Understanding dimension have no effect on the posttest scores of the two groups. This may possibly be explained by the fact that students from both groups are not used to reflecting on the knowledge that they already have prior to the implementation of the study. This outcome is supported by Lucas and Tan (2006), who clarified that understanding a construct comprises an understanding of a concept without necessarily reflecting upon its significance in personal or practical situations.

\section{Comparison of Posttest Mean Scores}

To determine if there was a significant difference in the students' reflective thinking skills and between the MAI and the NMAI groups, independent samples t-test was performed on their posttest mean scores as shown on Table 3.

Table 3. MAI and NMAI posttest mean scores in the Reflective Thinking Questionnaire

\begin{tabular}{lllllll}
\hline Components & Group & Mean & Std. Dev. & t & df & $\begin{array}{l}\text { Sig. (1- } \\
\text { tailed) }\end{array}$ \\
\hline Habitual Action & MAI & 11.30 & 1.92 & 3.22 & 87 & 0.001 \\
& NMAI & 10.09 & 1.59 & & & \\
Understanding & MAI & 14.34 & 1.31 & -0.26 & 87 & 0.42 \\
\multirow{2}{*}{ Reflection } & NMAI & 14.4 & 1.29 & & & \\
& MAI & 12.77 & 1.7 & 0.93 & 87 & 0.18 \\
& NMAI & 12.47 & 1.41 & & & \\
\hline
\end{tabular}




\begin{tabular}{lllllll}
\hline Critical Reflection & MAI & 12.25 & 1.62 & -1.38 & 87 & 0.09 \\
& NMAI & 12.73 & 1.68 & & & \\
Reflective Thinking & MAI & 50.66 & 3.62 & 1.30 & 87 & 0.10 \\
Skills (Overall) & NMAI & 49.69 & 3.39 & & & \\
\hline
\end{tabular}

It is important to note based on Table 3 that the overall mean score of the MAI $(M=50.66, S D=3.62)$ group is slightly higher than that of the NMAI $(M=49.69, S D=3.39)$ group, however, there is no significant difference in their reflective thinking skills. The improvement of the MAI group in their overall reflective thinking skills scores and in the Habitual Action dimension could be attributed to the metacognitive analogies and the guide questions given to them which required a considerable amount of focus and thinking. The use of metacognitive analogy is something new to them since most of the teachers in the public school are very much accustomed to the lecture method which limits students' active involvement in class. This result is in harmony with the findings of Song, Koszalka, and Grabowski (2005) wherein he claimed that reflective thinking results to students' creation of a concept about a situation in order to choose the best way to learn in that situation.

\section{Improvement of the Students' Reflective Thinking Skills}

The mean pretest and posttest scores in each of the four dimensions of Reflective Thinking Skills of the MAI and NMAI groups were compared to determine if there was an improvement that occurred after the intervention. Table 4 shows the comparison of the pretest and posttest mean scores of the MAI and the NMAI groups.

Table 4. Paired samples t-tests of the pretest and posttest mean scores of the MAI and NMAI groups in each of the four dimensions of RTQ

\begin{tabular}{llrlll}
\hline Components & Group & Pretest & Posttest & t & $\begin{array}{c}\text { Sig } \\
\text { (1-tailed) }\end{array}$ \\
\hline Habitual Action & MAI & 10.64 & 11.30 & -2.07 & 0.02 \\
& NMAI & 10.33 & 10.09 & 0.79 & 0.22 \\
Understanding & MAI & 14.52 & 14.34 & 0.65 & 0.26 \\
& NMAI & 13.93 & 14.4 & -2.06 & 0.02 \\
Reflection & MAI & 13.18 & 12.77 & 1.40 & 0.09 \\
& NMAI & 12.78 & 12.47 & 1.51 & 0.07 \\
Critical Reflection & MAI & 12.02 & 12.25 & -0.70 & 0.24 \\
\multirow{2}{*}{ Reflective Thinking } & NMAI & 12.02 & 12.73 & -2.25 & 0.01 \\
Skills (Overall) & NMI & 50.36 & 50.66 & -0.48 & 0.32 \\
\hline
\end{tabular}

Table 4 accentuated that there was no significant difference in the overall pretest and posttest mean scores of the MAI group. It is important to note, however, that in the Habitual Action $(\mathrm{p}=.02)$, there is a significant difference in the pretest and posttest mean scores. This only shows that despite the seemingly repetitive task given to the MAI group in the form of metacognitive analogies, they still had to think about the things that they were doing. In other words, they consistently reflected upon ideas before acting on them. This confirms the findings of Basol and Gencel (2013) that reflecting on an idea or situation can be a tool that can help students achieve their learning goals and turn 
them into the desired behavior. Students from the MAI group understood that considerable amount of focus is needed to successfully accomplish a given task.

On the other hand, there is also no significant difference in the overall pretest and posttest mean scores of the NMAI group. Surprisingly, it was found out that the Understanding $(\mathrm{p}=.02)$ and Critical Reflection $(\mathrm{p}=.01)$ components of the NMAI group showed a significant difference, meaning, that the group benefitted from the approach. During class instruction, students from this group showed that they were just introduced to new teaching strategies which gave them more understanding and control of their learning. The teaching strategies which are referred to are the ones which are already implemented in Philippine private schools for a long time like think-pair-share, gallery walk, and jig-saw-puzzle. This new way of learning gave the NMAI group a better and more exciting classroom experience. The NMAI group were also able to realize the importance of the learning material given to them. According to Guerrero's (2016) study, students learn to do things the way they are already accustomed to. However, the usual way they are doing things may not be the best way if the learner will only reflect on it. She also added that the key to change is improved practice. While these students were introduced to a new way of learning which they discovered to be more effective than the previous ones, they were able to infer using their own experience that meaningful learning can be achieved through more involvement in the process.

\section{- CONCLUSION}

Students exposed to MAI performed better than those exposed to NMAI in the Habitual Action dimension of reflective thinking skills. Both groups, however, exhibit the same performance in the Understanding, Reflection, and Critical Reflection dimensions. This improvement is the result of the use of metacognitive analogies with the aid of the guide questions given to the students which made them more focused on the task and helped improved their cognition that eventually led to reflective thinking. In addition, this teaching strategy is new to the students since most of the teachers in Philippine public schools are used to lecture method which does not encourage higher form of thinking among students. Finally, reflective thinking skill is significantly and positively correlated with motivation in Biology.

For further researches, it is recommended: (1) biology teachers and those from other disciplines can come up with classroom lessons as well as instructional materials using metacognitive analogy instruction that will improve reflective thinking skills; (2) teacher implementers of the senior high school can make use of metacognitive analogy instruction for the STEM track or academic track to promote reflective thinking that will facilitate understanding of difficult concepts and make biology topics more relevant; (3) principals, department heads, and science coordinators may initiate school- based trainings for their teachers or encourage them to attend seminar- workshops that will capacitate them to develop metacognitive analogy activities in order to motivate students and promote reflective thinking skills in Biology and other science classes; (4) curriculum and instructional developers can incorporate the development of metacognitive analogy lessons in the current science competences to further enhance the reflective thinking skills of students; and (5) Teacher Education Institutions (TEIs) should continuously prepare and train prospective and in-service science teachers to use the metacognitive analogy instruction in improving the reflective thinking skills of students. 


\section{- REFERENCES}

Akkuzu, N. \& Akcay, H. (2011). An effective model to increase student attitude and achievement: Narrative including analogies. US-China Education Review, 612-623. Retrieved from http://files.eric.ed.gov/fulltext/ED527688.pdf.

Amoroso, V. \& Bajo, A. (2014). Phl dropout rates rising since 2007. Retrieved from http://www.philstar.com/campus/2014/06/12/1333995/phl-dropout-rates-rising2007.

Başol, G. \& Gencel, İ. (2013). Reflective thinking scale: A validity and reliability study. Educational Sciences: Theory \& Practice, 13(2), 941-946. Retrieved from http://files.eric.ed.gov/fulltext/EJ1017318.pd.

Kember, D., Leung, D., Jones, A., YuenLoke, A., McKay, J., Sinclair, K., ... Yeung, E. (2000): Development of a questionnaire to measure the level of reflective thinking. Assessment \& Evaluation in Higher Education, 25(4), 381-395.

Demir, S. (2015). Evaluation of critical thinking and reflective thinking skills among science teacher candidates. Journal of Education and Practice, 6(18). Retrieved from http://files.eric.ed.gov/fulltext/EJ1079684.pdf.

Feliciano, J. S., Mandapat, L. R., \& Khan, C. L. (2013). Harnessing the use of open learning exchange to support basic education in science and mathematics in the Philippines. US-China Education Review, 3(6), 407-416. Retrieved from http://eric.ed.gov/?id=ED543809.

Flavell, J. (1979). Metacognition and cognitive monitoring: A new area of cognitivedevelopmental inquiry. American Psychologist, 34(10), 906-911.

Guerrero, C. G. (2016). Experiential-Reflective Teaching Approach: Effects on student environmental sensitivity and decision making skills (Unpublished master's thesis). University of the Philippines Diliman.

Harrison, A. G. \& Treagust, D. F. (1993), Teaching with analogies: A case study in grade-10 optics. Journal of Research in Science Teaching, 30, 1291-1307. doi: 10.1002/tea.3660301010.

Jonāne, L. (2015). Using analogies in teaching physics: A study on Latvian teachers' views and experience. Journal of Teacher Education for Sustainability, 17(2). doi:10.1515/jtes-2015- 0011.

Lucas, U. \& Tan, P. (2006, May). Assessing levels of reflective thinking: the evaluation of an instrument for use within accounting and business education. Paper presented at the 1st Pedagogic Research in Higher Education Conference, Liverpool Hope University, Liverpool.

Maurer, T. W., Allen, D., Gatch, D. B., Shankar, P., \& Sturges, D. (2013). A comparison of student academic motivations across three course disciplines. Journal of the Scholarship of Teaching and Learning, 13(5), 77-89.

Mullis, I. V. S., Martin, M. O., Gonzalez, E. J., Chrostowski, S. J. (2004). TIMSS 2003 International Mathematics Report: Findings from IEA's Trends in International Mathematics and Science Study at the Fourth and Eighth Grades. Chestnut Hill, MA: Boston College.

Orleans, A. V. (2007). The condition of secondary school physics education in the Philippines: Recent developments and remaining challenges for substantive improvement. The Australian Educational Researcher, 34(1), 33-54.

Remigio, K. B. (2012). Analogy-Enhanced Instruction: Effects on Reasoning Skills in Science (Unpublished master's thesis). University of the Philippines Diliman. 
Sendur, G., Toprak, M., \& Pekmez, E. (2011). An analysis of analogies used in secondary chemistry textbooks. Procedia Computer Science, 3, 307-311. https://doi.org/10.1016/j.procs.2010.12.052

Song H. D., Koszalka T. A., \& Grabowski B. L. (2005). Exploring instructional design factors prompting reflective thinking in young adolescents. Canadian Journal Learning Technology, 31(2), 120-132.

Ugur, G., Dilber, R., Senpolat, Y., \& Duzgun B. (2012). The effects of analogy on students' understanding of direct current circuits and attitudes towards physics lessons. European Journal of Educational Research, 1(3), 211-223.

OECD. (2019). PISA 2018 Insights and Interpretations. OECD Publishing. Paris. Retrieved from: https://www.oecd.org/pisa/PISA\%202018\%20Insights\%20and\% 20Interpretations \%20FINAL\%20PDF.pdf 